\title{
Opportunities and Challenges of Academic Staff in Higher Education in Africa
}

Elijah Dickens Mushemeza ${ }^{1}$

${ }^{1}$ Centre for Budget and Economic Governance, Advocates Coalition for Development and Environment, Kampala, Uganda

Correspondence: Elijah Dickens Mushemeza, Advocates Coalition for Development and Environment (ACODE) Plot 96, Kanjokya Street, Kamwokya P.O Box 29836, Kampala, Uganda. Tel: 256-312-812-150

Received: July 10, 2016

doi:10.5430/ijhe.v5n3p236
Accepted: August 2, 2016

URL: http://dx.doi.org/10.5430/ijhe.v5n3p236

\begin{abstract}
This paper analyses the opportunities and challenges of academic staff in higher education in Africa. The paper argues that recruitment, appointment and promotion of academic staff should depend highly on their productivity (positive production per individual human resource). The staff profile and qualifications should be posted on the University website in order to promote publicity and networking among scholars.

The paper observes several challenges that face the African Universities today - funding (enhancement of financial base and sustainability), infrastructural demands, inadequate staff remuneration, high student enrollment with low staff-student ratio, and governance/management deficits. In spite of these challenges, it is possible to identify and implement strategic interventions to admit quality students/optimum level of student intake, appoint and retain quality academic staff if we are to build a well-functioning University for both institutional and society development in Africa.
\end{abstract}

Keywords: Academic staff, Productivity, University, Development

\section{Introduction}

Africa today faces a multiple of development challenges ranging from policy design to implementation, monitoring and assessment of the outcomes in relation to resources invested and service delivery in the field of higher education. Government investment in several African public Universities is dwindling and yet research is critical for understanding and designing appropriate policies and legislations for responding to the existing challenges. For quality research, African university must of a necessity recruit and retain quality academic staff for higher productivity. But how has the African University responded to this dilemma in the wake of decreasing financing in public Universities? What should be done to recreate a research University in Africa with academic staff capable of carrying out productive research not only generating knowledge but also for consumption of policy makers and implementers on the continent? Using documentary evidence from published works, University data bases available on the Internet, this paper carries out a thematic analysis of the African University historically, the challenges it has faced in recruiting and retaining quality academic staff and the necessary interventions that would recreate the research University for better academic service delivery and development.

\section{Higher Education and Academic Profession in the Broader African Setting}

Worldwide, institutions of higher learning trace their roots as early as the third century A.D. with some of the features of the time surviving up to the present day (IAFW, n.d.). Until recently, Euro-centrist history professors taught that it was the Europeans who brought higher education to the African continent (Lulat 2005). 'While the Europeans have indeed influenced African education for quite some time, there is vital information that most history books leave out: for centuries before the arrival of the Europeans, the vast and advanced native African civilizations already had sophisticated universities and other institutions of higher education to boast about' (Lulat 2005).

Indeed, Africa has had institutions of higher learning for centuries, including those of indigenous, Islamic and, later, western origins. The earliest recorded universities appear in the northern part of the continent, most notably in Egypt and Morocco. 'The University of Al-Karaouine was established in Fez, Morocco, in 859 A.D. and is considered as one of the oldest continuously operating universities in the world' (Esposito 2003). It played a leading role in relations between the Islamic world and Europe in the middle Ages (http://www.muslimheritage.com). Similarly, 
Al-Azhar University in Egypt, connected to Al-Azhar mosque, is believed to have been founded around 969/970 A.D. and became a pre-eminent seat of Arabic-Islamic learning (Esposito 2003). Other sources however, place Timbuktu as the oldest university in the whole world (http://www.africanecho.co.uk), while Mustansiriya University of Sankore (1327) was built much later in Mali. Lulat (2005) observes that 'in those places that possessed institutions of higher learning, the pursuit of knowledge for its own sake was a recognised good'.

When the colonial era set in, more universities were established on the African continent, although these were not independent but semi-autonomous, affiliated to other universities found in the mother countries of the colonial masters. It was through linkages with Universities in Europe, that issues of quality assurance, quality staff development and funding were boosted. Materu (2007) however, observes that:

Authority over the quality of university education in those early days was a function of their governing boards and faculty. With affiliation, the institutions automatically became part of the British, French, Portuguese or other systems of quality assurance through their partner universities. These institutions were subject to the same kinds of quality control as were British or other European universities, including external examiners and other aspects of these systems (Materu 2007).

Materu further explains that as 'other new universities were established, some of them were also affiliated with external institutions. Over time, some of the first institutions, such as the University of Cape Town, became mentors for younger institutions in South Africa, as was the case for Fort Hare University which was affiliated with Rhodes University'. In Uganda, the then Makerere College was elevated to the level of the University College of East Africa (1949) but attached to the University of London, the latter acting as a watchdog in regard to the quality of education over the former.

From the University of East Africa, established in 1963, three more Universities emerged in 1970, namely; the University of Nairobi, the University of Dar es salaam in Tanzania and Makerere University in Uganda. 'In Sudan, the Gordon Memorial College, established in 1902 by the Anglo- Egyptian Condominium, entered into a special relationship with the University of London and instituted degree programmes. It evolved into Khartoum University College in 1951 and in 1956 became Khartoum University' (Kanangire 2010). In Ethiopia, Haile Selassie I University was created in 1961 from the University College of Addis Ababa, which had been established in 1950, and it became the Addis Ababa University in 1975(Kanangire 2010).

In the period that followed independence i.e. 1960 and 1970s, higher education was limited with one University per country in most cases. Although the quality of graduates and research output was high, higher education was indeed a privilege of the few. The situation, however, changed in the 1980s and 1990s. African states realized the need to have an educated mass in various fields - engineering, medicine, agriculture, economics, public administration and management, development studies for a multi-disciplinary approach - to support economic growth and development. This was a time of increased population growth. More secondary schools were built and produced large numbers that yearned for University education. As a result governments established more public universities, institutes, and colleges in their respective societies but with the majority of institutions located in cities and urban centres.

As Eshiwan, (1999) cited by Tjeldvoll et.al 2005; and Kanangire 2010 put it 'the main challenge of African Universities became the necessity to expand their services rapidly, from the education of the elite to mass education, despite limited financial resources'. This demand situation forced governments to liberalise higher education and licensed several private universities and institutes to provide the much needed service. 'In Ethiopia, Addis Ababa University enrolled over 33,600 students in 2007/08 from 12,500 in 2003/04' (Alemu 2010). 'In Kenya Nairobi University enrolled 49,000 students in 2010' (Mwiandi 2010) 'while in Burundi students enrollment for higher education moved from 3,821 in 1991-92 to 21,158 in 2005/06' (Barakamfitiye 2010) and in 'Egypt the number of students is over 2.6 million in eighteen public universities, twelve colleges and fifteen private institutions' (Alemu et.al 2010).

Although the establishment of more institutions has increased opportunities for both parents and their children to access higher education, it is also a fact that weak students have joined universities and other institutions and their performance is not the best. Lecturers and Professors are overloaded with little time space to prepare for lectures, mentor students, attend an international conference when funds allow and conduct research. In institutions where government sponsored programmes run parallel to those privately sponsored ones, the academic staff is overwhelmed by the practice of teaching more hours to earn an extra income. 
In some African countries, however, political instability that resulted from struggles for power has undermined the university space. Indeed universities collapsed or are limping in Somalia, Angola and Democratic Republic of Congo (Teferra and Altbach 2004).

In broad terms, today globalisation has created new challenges to a university and the delivery of higher education in general. Zelesa and Olukoshi (2004:3) raises a number of questions or dilemmas that face the African university amidst technological change, weakened capacity of the African state in most African countries after nearly two decades of unrelenting economic crises and orthodox structural adjustment. 'The dilemmas according to the authors centre on: 'How to balance autonomy and viability, expansion and excellence, equity and efficiency, access and quality, authority and accountability, representation and responsibility, diversification and differentiation, internationalisation and indigenisation, global presence/visibility and local anchorage, academic freedom and professional ethics, privatisation and the public purpose, teaching and research, community service/social responsibility and consultancy, diversity and uniformity, the preservation of local knowledge systems and the adoption of global knowledge systems, knowledge production and knowledge dissemination, the knowledge economy and the knowledge society'.

All these questions are a reality and relate to the most rapidly expanding higher education sector in middle-income and developing countries. However, our main concern in this paper is how quality academic staff can be recruited, promoted and retained in higher institutions for a better service delivery. Service delivery in this case entails, academic productivity (quality teaching, research, publication and dissemination), doctoral training and professional excellence. This is because quality academic staff has a direct link to the development of a well-functioning university and the growth and stability of the academic profession and development in Africa in the $21^{\text {st }}$ century.

\section{Core Responsibilities of an Academic Staff in a University}

World over universities agree that their core function centre around four areas; teaching, research, publishing and outreach. This is possible when universities recruit, train and retain quality academic staff. There are other factors which are important but we will discuss them later particularly, governance/management, quality of students, financial resources, infrastructure etc. The centrality of quality academic staff is a reality in terms of designing relevant programmes and courses, teaching, examination and supervision of students' research.

The academic staffs are expected to be scholars who produce knowledge mainly through research. A scholar must constantly create the knowledge he/she delivers to students (NCHE 2011:9). In other words, a scholar is a person who studies independently and continuously in search of truth as he/she tries to understand a phenomenon and where necessary solves a problem that bothers society.

When research has been accomplished, academic staff is expected to publish books and articles in recognized academic Journals. It is also acceptable to publish monographs, working papers and policy papers. This is important for dissemination to the wider society for utilization. However, quite often, academic intellectuals write in sophisticated language making it difficult to those outside the university and in some cases even those inside the university to read and understand what has been communicated. For academicians to be relevant in the $21^{\text {st }}$ century, their works must be able to be appreciated and understood by sizeable sections of society in which the research problem addressed is valuable.

The other important core function of a university is "where the academic staff is expected to make a contribution is community outreach. Modern universities are supposed to be leaders in the social and economic development of their communities and nations and this raises the question of the relevance of their programmes and research' (NCHE 2011:19). It is therefore important for academic staff to design programmes and projects that focuses on the community needs and aspirations, the market and general society. They are also expected to engage in effective internship programmess, lead the way in building linkages that allow community participation in university activities and making regional collaboration a reality

Quality staff in a university has been found to be useful to the wider society in terms of consultancy services offered. The academic staff with skills and competencies is engaged in consultancy assignments which bring money to the university. University consultants use their research skills to solve problems as requested by clients. Governments, NGOs, Intergovernmental organizations like UN, Banks, and enterprises quite often engage academic intellectuals in consultancy assignments that benefit, not only the clients but the wider society of humankind.

\section{The Legal Perspectives on Academic Staff Recruitment in Africa}

In Africa governments have put in place legislative instruments and established regulatory institutions to maintain quality in higher education. Yet the implementation of the required standards remains a huddle. In Kenya, the 
Universities Act of 1985 established the Commission for Higher Education (CHE). The CHE places great emphasis on the academic focus-with quality assurance measures aimed at the promotion of academic standards in programme delivery. 'Both Private Universities and Public Universities are expected to meet the standards set for university education on pertinent issues such as admission requirements, programme length, qualification levels of enrollment of students, quality issues, minimum academic requirements for staff, infrastructural facilities and ethical standards by which the university staff should be governed' (Thaver 2004 cited in Alemu et. al., 2010).

In Uganda the University and Other Tertiary Institutions Act, 2001, section 119 provides that "no University or Tertiary institution shall employ a lecturer or other person recruited for the purpose of teaching or giving instructions to students whose qualifications do not conform to the standards set by the NCHE by regulations'. The standards are provided in Statutory Instrument No. 50 of 2010. All universities are required to have publically known rules and regulations for hiring, promotion and firing staff. The compliance to this statutory instrument enables universities to design quality assurance mechanisms and maintain quality control.

In Ethiopia, Proclamation No.351/2003 - 'the Higher Education Proclamation provides for the modes of governance and operation of higher education. Institutions both public and private are governed by the same legislation. Similarly in Sudan, the National Council of Higher Education and Research was created by the 1990 Higher Education Reform Act (amended in 1993 and 1995). It is vested with wide-ranging powers relating to formulating policies and developing programmes that are in line with overall priority areas of government policy' (Abdalla and Elhadary 2010).

Table 1. Recommended qualifications for academic staff in some East African Universities

\begin{tabular}{llll}
\hline Academic Position & Research Position & Library Position & Qualifications \\
\hline Teaching Assistant & Assistant Research Fellow & Library Assistant & $\begin{array}{l}1^{\text {st }} \text { Degree Class/Upper } \\
\text { Second Hons }\end{array}$ \\
Assistant Lecturer & Research Fellow & Assistant Librarian & Masters Degree \\
Lecturer & Senior Research Fellow & Librarian & Masters Degree \\
Senior Lecturer & Research Associate & Senior Librarian & $\mathrm{PhD}$ \\
Associate Professor & Research Professor & Deputy Chief Librarian & $\mathrm{PhD}$ \\
Professor & & Chief Librarian & $\mathrm{PhD}$ \\
\hline
\end{tabular}

Source: NCHE, Statutory Instrument No.50 of 2010.

From Table 1, the NCHE in Uganda like some universities in East Africa set very impressive standards for academic staff. The quality of a person at the point of entry i.e. teaching Assistant/equivalent and Lecturer/equivalent is crucial. Some Lecturers with Masters Degree who are serving in most private universities have been found to be wanting in terms of research skills and availability. The tendency is to operate as if the role of an academic is just teaching and marking examinations. Universities in the $21^{\text {st }}$ century require a full-time member of academic staff who must: teach a prescribed teaching load (in terms of teaching hours per week, per month and per semester); be available to students outside lectures; do research; supervise students research, assess students by way of take home exercises, tests, exams, research or internships reports; attend Departmental/Faculty meetings; participate in the university outreach programmes; and execute other responsibilities assigned to him/her by the Head of department. It is this kind of staff that the university organ responsible for recruitment will be looking for.

In some countries African governments have enacted laws which also require universities to respect academic freedom (the freedom of every individual/staff/student, to act freely in pursuit of knowledge). In enjoying this freedom, academic staff is expected to teach, learn, speak, and write without interference; set and implement research agendas; and hold and express opinions instrumental to scholarship without interference from university administration, the government, civil society, funders or parents. These values are shared elsewhere on the African continent (Kampala Declaration, 1990). In some countries like Sudan the law is negative to academic freedom. The Higher Education Act stipulates that the President of the republic is the Chancellor of all higher education institutions, with power to appoint and dismiss vice-chancellors and their deputies, including the chairpersons of university councils and most of the council members. The point is African states as matter of principle and practice should promote academic freedom if institutions of higher learning are to make the expected contribution to state building. 


\section{Profile and Qualifications of Academic Staff in Selected Universities in Africa}

Rationale of having profiles and qualifications of academic staff made public

A profile of an academic staff provides opportunity to interested stakeholders to know the involvement of an academic in research and scholarship which underpins the high quality of teaching of university's courses. A profile also avails interested individuals, potential students and parents/guardians to know the extent an academic has made a contribution in consultancy with private and public sector organizations, professional associations, adviser on government bodies, conducting research, and his/her work in collaboration with other academics at home and abroad. Such profiles are usually found on university websites.

In a contemporary world with ICT facilities, universities are constantly looking for quality staff, while academic intellectuals are continuously looking for competent, skilled and hardworking scholars to collaborate with. It is therefore important for university websites to provide profiles and qualifications of their staff. This can be organised at the level of a Department, Faculty or School. The profile of an academic staff would also be monitored in as far as it is consistent with the core values and functions of the institution. The academic staff is expected to balance excellence across the core functions/priority areas of the university. When this is done, there is likelihood to deliver more students, incomes, improved image and the overall growth and stability of the institution.

Available staff in selected universities in Africa

a)

Table 2. Number of staff in Sudanese higher education institutions by academic rank and gender in 2003

\begin{tabular}{lllllllllllll}
\hline $\begin{array}{l}\text { Type of } \\
\text { University }\end{array}$ & Professor & \multicolumn{2}{l}{$\begin{array}{l}\text { Associate } \\
\text { Professor }\end{array}$} & \multicolumn{2}{l}{$\begin{array}{l}\text { Assistant } \\
\text { Professor }\end{array}$} & Lecturer & \multicolumn{3}{c}{$\begin{array}{l}\text { Teaching } \\
\text { Assistant }\end{array}$} & Total & \\
\hline Public & F & M & F & M & F & M & F & M & F & M & F & M \\
& 14 & 415 & 101 & 686 & 345 & 1,414 & 1,094 & 1,830 & 686 & 1198 & $\mathbf{2 2 4 0}$ & $\mathbf{5 , 7 2 5}$ \\
Private & 5 & 56 & 21 & 152 & 53 & 158 & 232 & 282 & 210 & 244 & $\mathbf{5 2 2}$ & $\mathbf{9 1 0}$ \\
Total & 19 & 471 & 122 & 838 & 398 & 1,572 & 1,426 & 2,112 & 896 & 1442 & $\mathbf{2 , 8 6 1}$ & $\mathbf{6 , 4 3 5}$ \\
\hline
\end{tabular}

Source: MHESR, 2003 - Adopted from Alemu et. al., 2010

Student enrollment in higher education has been increasing rapidly. In 2000/01, 43,518 students were admitted; 2005/06 58,906 were admitted; 2006/07, 78,592 were admitted (Abdalla and Elhadary 2010). The same author argues that 'increased student enrollment has not been matched by a corresponding deployment of qualified teaching and research staff. The situation is worse in newly established universities'. This shortcoming according to (Abdalla and Elhadary 2010:190), is serious especially regarding the number of staff with academic credentials like PhD degrees and professional ranks.

b)

Table 3. Makerere University: qualifications profile of academic staff as at 21 September 2009

\begin{tabular}{lllllllll}
\hline & PhD & & Masters & \multicolumn{3}{c}{ Bachelors } & Total \\
\hline & Female & Male & Female & Male & Female & Male & Female & Male \\
Professor & 2 & 39 & 1 & 3 & 0 & 0 & 3 & 42 \\
Associate Professor & 10 & 57 & 4 & 11 & 0 & 2 & 14 & 70 \\
SeniorLecturer & 29 & 83 & 16 & 50 & 0 & 0 & 45 & 133 \\
Lecturer & 33 & 92 & 60 & 154 & 1 & 13 & 94 & 257 \\
AssistantLecturer & 6 & 3 & 107 & 210 & 15 & 31 & 128 & 244 \\
TeachingAssistant & 0 & 2 & 8 & 25 & 90 & 172 & 98 & 199 \\
Total & $\mathbf{8 0}$ & $\mathbf{2 7 6}$ & $\mathbf{1 9 6}$ & $\mathbf{4 5 3}$ & $\mathbf{1 0 6}$ & $\mathbf{2 1 8}$ & $\mathbf{3 8 2}$ & $\mathbf{9 4 5}$ \\
\hline
\end{tabular}

Source: www.mak.ac.ug

The situation at Makerere University in Uganda is no better compared to public universities in the Sudan. With a population of over 30,000 in 2006, the number of senior academic staff is still low to manage effective supervision at Masters and PhD levels. The limited number of PhD holders is reported at the University of Dar es salaam, and 
National University of Rwanda. The situation is similar in Egypt. El-Rayes and El-Emam (2010:73) have argued that 'the number of assistant researchers in social science faculties, in general, is more than the number of staff with $\mathrm{PhD}$ degrees, which means that social science faculties will continue to suffer extreme student-staff ratios if the unequal distribution of students between the different faculties continues. Few staff members are available to supervise postgraduate students in the social sciences because the staffs that are available are overloaded with undergraduate teaching responsibilities.'

Table 4. Existence of staff profiles on university website of selected public institutions

\begin{tabular}{|c|c|c|c|c|c|}
\hline Name & Category & $\begin{array}{l}\text { Available and } \\
\text { enriched }\end{array}$ & Scanty & $\begin{array}{l}\text { Available and } \\
\text { enriched }\end{array}$ & Scanty \\
\hline & & 2011 & 2011 & 2016 & 2016 \\
\hline University of Ibadan & Public & & $\mathrm{X}$ & $\mathrm{X}$ & N/A \\
\hline University of Cape Town & Public & & $\mathrm{X}$ & $\mathrm{X}$ & N/A \\
\hline University of Nairobi & Public & & $\mathrm{X}$ & $\mathrm{X}$ & N/A \\
\hline MakerereUniversity & Public & & $\mathrm{X}$ & $\mathrm{X}$ & $\mathrm{N} / \mathrm{A}$ \\
\hline Addis Ababa University & Public & & $\mathrm{X}$ & $\mathrm{X}$ & N/A \\
\hline
\end{tabular}

Source: Respective University websites, September, 2011 and June 2016. N/A: Not applicable

\section{Implications of Existence and Non-existence of Staff Profiles on University Websites}

Table 4 shows that some selected universities in Africa in 2011did not have enriched academic staff profiles posted on their websites. This has however, improved over the last five years. But many universities are yet to follow the example of the selected case studies. This weakness puts the universities in a disadvantaged position at African level and beyond. As Hsuan Feng (2007) put it a 'World Class University (in this case an aspiring one) is a place where people will want to spend time learning from and being with the best minds around, and to associate with the fame and respect that goes with this'. A university whose best brains (in terms of staff) are not known to a network of other scholars will not be attractive to them. How will students from other countries be attracted if they cannot find the faculty members who would supervise them in their field of interest?

In an era of globalization, where the Internet is a major source of information for opportunities, staff profiles that are made public would attract more students and increase enrollment. Increased enrollment from a wide spectrum is likely to attract the best of the brightest into various programmes. This is likely to increase international linkages in terms of research, joint degrees and funding. African universities therefore must embark quickly on this important undertaking in order to compete and become world class universities. Again to borrow a word of wisdom form Hsuan Feng (2007:68), 'for better or for worse, knowledge is now bought and sold as a commodity. Research institutes, think tanks and consulting firms are all new competitors to Universities in the knowledge economy'. Universities in Africa cannot continue to avoid enriching their websites with academic staff profiles which are critical in the competition referred to above.

\section{Academic Productivity and the Development of a Strong University in Africa}

We have already discussed the core functions of a university. However, the African university has been undergoing rapid changes, some being negative. What therefore is needed in most African countries is the development of a strong university that balances all the core functions alluded to above. It is a university that studies the challenges and prepares appropriate responses in time for both the present and the future.

This is possible through admission of quality students and academic staff and providing an enabling environment for academic productivity (positive production per each individual human resource or staff). It also includes initiating graduate programmes particularly training of $\mathrm{PhD}$ students. $\mathrm{A} \mathrm{PhD}$ is considered to be research training and should be one of the valued preconditions to be considered for employment by a university in the $21^{\text {st }}$ century. When a PhD holder eventually is promoted to a Professor, he/she is expected to provide academic leadership in designing teaching programmes, research, publication and dissemination of knowledge. For $\mathrm{PhD}$ supervision, professors should be grounded in research methodology in which both qualitative and quantitative methods of data collection and analysis are encouraged. PhD students who integrate both methodologies are likely to produce better analysis of the identified research problem. 
The productivity of the academic staff should therefore be measured in terms of teaching load and the candidates graduated, research being undertaken and completed, publication of Journal articles, books, monographs and community outreach. It should also be measured in terms of young scholars being mentored and the contribution of the university to the community. This is where applied research (done to solve particular problems of society) is vital. Community outreach in this regard encompasses participation in their development and leadership activities e.g. sitting in school boards, church councils, and microfinance institutions committees or participation in a community utility project such as water or power supply.

Promotion - In African universities 'there are allegations of delays in promotion due to long procedures and high demands on productivity of an individual academic' (Tettey 2006). Whereas there could be cases of lack of transparency in some universities, it is also true that some academic staff would like to be promoted on the basis of teaching and grading students alone especially those at the levels below the rank of a professor. Yet this undermines the development of research and publication activities in the university. In my view, as noted earlier, promotion should be considered for full time staff who have executed prescribed and known responsibilities appropriately, teach a prescribed teaching load (in terms of hours per week, per month and per semester); be available to students outside lectures; do research; supervise students research; assess students by way of take home exercises, tests, exams, internship; attend and contribute positively in departmental and faculty meetings; participate in the university's outreach programmes; and execute other responsibilities assigned to him /her by Head of department). The staff would be assessed on those points using a designed instrument of assessment for various levels/ranks.

\section{Challenges that Face Universities in Quality Staff Retention}

African universities face numerous challenges. I have discussed the significance of having academic staff profiles on their websites. However, networking scholars are looking for quality staff to make linkages. Why are African universities loosing scholars to the Diaspora, government, Think tanks and other private companies or civil society organizations?

First is the factor of funding higher education. There is a debate on whether the state/government should meet the bulk of financing higher education in Africa. There is also the view of encouraging private-public partnerships in financing higher education. While supporting private - public partnerships, Mamdani (2007:236) warns us of 'the danger/tendency to change the academic curriculum in response to market demands, uncritically and across the board thus failing to distinguish between privatization and commercialization'. He argues and correctly so that 'commercialization of higher education undermines efforts of building a research university, the only entity that can provide the institutional framework for sustaining intellectual thought'.

The issue of funding and particularly the welfare of staff at various universities in Africa have been at the centre of a series of strikes since 1990s. Inadequate remuneration in form of salaries has resulted into several unfortunate consequences particularly;

- Low morale and self-esteem

- Resignation to join better paying institutions after being sponsored for advanced degrees

- Low productivity and poor outputs especially in research and innovations

- Limited time allocation to research and publication resulting into stagnation of staff in posts

- Inability to pay household utility, food, school fees and health care bills regularly.

It has been reported (Tettey 2006) that 'some academic staff approaching the decade prior to retirement, get very anxious about the financial trepidations that tend to accompany retirement. They therefore make decisions about quitting academia in good enough time and taking up positions that are better paying and consequently are more likely to enable them accumulate enough to ensure a more comfortable retirement, even if they do not get a large pension'. 
Table 5. Comparative salary scales of academic staff among universities in Africa (Average Gross Salary per Annum in US \$)

\begin{tabular}{|c|c|c|c|c|c|c|c|}
\hline Position & 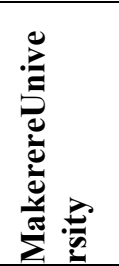 & 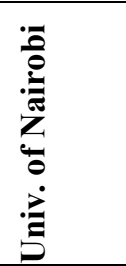 & 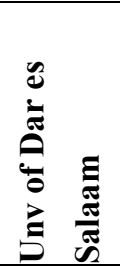 & 主 & 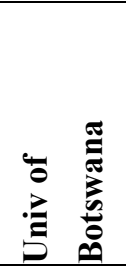 & 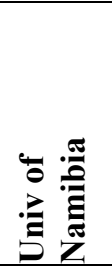 &  \\
\hline Professor & 12,972 & 27,612 & 21,228 & 23,447 & $\overline{47,198}$ & 40,026 & 31,967 \\
\hline Associate Professor & 12,428 & 23,197 & 19,460 & 22,774 & 43,990 & 34,604 & 30,033 \\
\hline Senior Lecturer & 10,533 & 18,883 & 15,492 & 18,592 & 40,205 & 30,260 & 25,080 \\
\hline Lecturer & 8,998 & 16,959 & 11,750 & 17,378 & 31,279 & 28,542 & 22,532 \\
\hline AssistantLecturer & 8,840 & 14,768 & 9,609 & n.a & n.a & 22,460 & 19,362 \\
\hline TeachingAssistant & 7,440 & n.a & n.a & n.a & n.a & n.a & n.a \\
\hline
\end{tabular}

Source: Makerere University Staff, September, 2011 cited from Association of Commonwealth Universities, 2011

The comparison in Table 5 clearly shows a significant disparity in salary scales and salaries of academic staff at public universities and some private universities as being low. This largely explains why universities in Africa are struggling to retain quality academic staff. It is therefore clear that the more a university invests in competition for quality (both in terms of staff remuneration and infrastructure facilities) the better it will become.

The other challenge related to funding is the continuously escalating operational costs in universities which require prudent use of resources secured and cost control. Universities must of necessity engage in resource mobilisation from both internal and external sources. Similarly, prudent use of resources calls for adequate planning, honest, positive attitudes/behaviour and courageous budget administration (use of a well-designed budget framework). Given these realities of the $21^{\text {st }}$ century, various stakeholders in a university must be mindful of the imbalances/gaps between what is needed and what is available; what is needed and what is feasible given the resource constraints; and, what is ideal and reality.

African universities particularly new and private ones are faced with heavy infrastructural needs/demands (both physical and technological). The increase in number of students year after year requires more lecture rooms, ICT laboratories, expanded libraries, academic staff offices, and recreational facilities.

The governance/Management question is yet another challenge that faces universities in Africa. Universities in Africa have clear governance bodies; the university council, boards of council, senior management. Such governance organs are important for participation and democratic governance generally. As Hsuan Feng (2007) put it 'the simple and inescapable truth is that universities must be managed diligently, prudently and professionally in a good setting to preserve and hand down core values to new generations'

\section{Strategic Interventions Necessary to Build a Strong and Well-functioning University in Africa}

In a study carried out in five Anglophone universities in Sub-Saharan Africa - Universities of Botswana, Ghana, Ibadan, Kwazul-Natal and Makerere University- Tettey (2006) suggests a number of interventions critical in reversing Africa's loss of its intellectual capital. From my analysis i find some of his suggestions still relevant today. We therefore incorporate his suggested interventions in our recommendations below particularly, on appointments and promotion; institutional governance, research and professional development; salaries and benefits; and the role of other key stakeholders.

Recruitment, Appointment and promotion - I have pointed out that quality academic, highly trained and experienced staffs are central to building a strong and well-functioning university. This means recruitment, appointments and promotion of potential candidates and existing ones must be done professionally. 'African universities therefore should avoid frustration and tardiness of appointment and promotion process and foster transparency, by ensuring that they are devolved to faculties, and anchored in a representative committee system at every level' (Tettey 2006). In addition National Commissions of Higher Education in Africa should harmonise academic promotion criteria. Quite often senior academics retire from public institutions when they are still very productive. In this regard universities should reconsider the retirement age for academics at least, as a short term measure to ensure that the institutions are staffed by qualified personnel until long term solutions are found. Indeed, 
there is a common saying in Africa that 'we have several Professors who retired from public universities but are not tired'. They can still be engaged on contractual terms both in public and private universities to mentor young scholars while at the same time attract research funding from international development partners through well-developed proposals.

Institutional Governance and Workplace Climate - In a study comprising of federal, state and private universities in Nigeria on leadership behavior of university Vice-chancellors and its implications to the work behavior of academic staff, Oke. G.G et. al. (2010) makes interesting revelations. The authors found out (among various hypotheses tested) that 'the lecturers' level of perception of their Vice-chancellors leadership behavior has a significant relationship with their level of participation in university activities'. This implies that in order to enhance lecturers' participation (read academic staff) in university activities, a Vice-chancellor need to exhibit positive leadership behavior. From their findings, they recommend a 'leadership training programme for Vice-chancellors. This type of leadership training programme could cover areas such as the dynamics of human behaviour, personnel functioning and administrative ability management, the politics of planned change, governance, organizational behavior and other key leadership competences'. Indeed, African University leaders should embrace more training for better governance and service delivery

Leadership of African universities is very crucial in building the university we all desire. Hsiou-Hsia (2007:58) observes and correctly so that 'the intellectual depth, elegancy, vision and most of all courage of a President/Vice-chancellor are direct reflections of the heart, soul and quality of the university'. He further observes that 'the quality of any university's leadership reflects that of the university. If one excels, so would the other; if one faulters, so will the other.' A Vice-chancellor for instance or any other senior administrator in higher institutions of learning must be aware and cognizant of the 'optimisation principle' commonly taught in economics schools. Such an administrator needs to be 'aware of the dichotomy that often arises between the interests of proprietors/institution (such as its survival, growth and development) on one hand; and the interests, needs and demands of staff and students on the other. He/she needs to be constantly aware of the possible implications and consequences of his/her decisions and actions as some of these will be positive and others negative' (Bibangambah 2009:22-3).

It is therefore recommended that African universities should offer training programmes for newly appointed administrators to acquaint them with different skills needed to accomplish the demands of their role. Furthermore, universities should address concerns around governance at unit and institution-wide levels through the establishment of representative committee structures, transparency in decision making, genuine consultative processes, and open channels of multi directional communication. Similarly, staff members should also be willing to participate in these structures and processes, and have a responsibility to keep them informed about various guidelines, regulations and procedures. Indeed when staff are represented on key governance organs of the university - council, boards of council, Senate, Senior Management etc. it increases transparency, accountability, balanced decision making and ultimately confidence and high retention.

Teaching, Research and Professional Development - In our analysis we noted high enrollment of students with few highly academic staff in some African universities. As a result most academic staff is engaged in teaching undergraduates with little time to engage in research and professional development. 'There is evidence that universities in Africa contribute less than 1 percent in international referred Journals. The contribution of African universities to World's scientific publications is only 1.4 percent with more than half of these coming from Egypt and South Africa' (Hassan 2008). Yet, for a university to be relevant its academic intellectuals must engage in quality teaching and researches that reflect the scientific and technological needs of society. "It is prudent for universities to insist on optimum level of student intake, under current circumstances, to address workload problems and release some energy to both basic and applied research. Universities should provide institutional support for mentoring programmes; institute starter grants and innovation grants for junior scholars; increase research and conference grants, forge research linkages with other institutions in Africa and abroad, as well as with governments and the private sector'. Academics staff should post their profiles on the university websites for all interested in the world of academia and public policy. Scholars, students, practitioners, indeed would want to spend time learning from the best minds, and to associate with the fame and respect that goes with such interaction as already noted. It is through university websites, one can easily find such experienced minds/scholars.

Salaries and Benefits - In the last three decades, African universities have been characterised by high tensions between academic staff and students on one side and the administration and proprietors/government on the other. In several instances academic staff has withdrawn their labour (laying down their tools) due to inadequate remuneration and scholastic materials. The academic intellectuals are the most highly trained human resource in society and yet 
they are poorly paid or rewarded both in monetary and non-monetary terms. This is why there is a high turnover of academic staff in African institutions of higher learning. I therefore recommend that institutions should work towards a reasonable improvement in the working conditions (salary and non-salary) of staff, because this is likely to result in more than proportionate levels of job satisfaction. It is necessary to implement some system of differential rewards. This is inevitable if certain academic fields are to attract and retain quality and experienced staff.

Role of Governments, the private sector and International Partners - In a globalised world, the private sector and international development partners like, African Development Bank, IDRC, SIDA-SAREC, are increasingly becoming important in financing/supporting higher education programmes. Although African governments are urged to increase financial support to universities, it is those institutions with private sourced component that are likely to achieve the dream of a strong and well-functioning university and be among the top ones on the continent. In this regard, international and private sector efforts at strengthening material resources and institutional capacity; ICT skills, training and research capacities in leadership and governance in African countries should be mobilised. 'Networking among African universities including mobilistaion of African scholars in the Diaspora to support the rebuilding of the African university is urgent. Such support would be but not limited to areas of programme and course designing, quality assurance and quality enhancement, publications (editing Journal articles, review of articles, joint writing of conference papers), sandwich doctoral training, website designing and development, library acquisitions, information sharing on scholarships and research grants'(Tettey 2006).

\section{Conclusion}

This paper has argued that the African University has faced numerous challenges to play its role of generating knowledge and policy alternatives for society's development. Productive research is possible when the University recruits, trains and retains quality academic staff. It is also possible to locate which University has quality staff if their profiles are published on the University websites. Students, policy makers, researchers are more interested in those institutions that demonstrate being world class Universities, a quality that African Universities should strive to have.

I have also argued that governance and leadership of university is critical in recreating the research University Africa needs. This is a leadership that must be mindful of the optimization principle where, the interests of various stakeholders are balanced. In that endeavor, attention will have to be paid on: professional mechanisms of recruitment, appointment and promotion; quality teaching and researches that reflect the scientific and technological needs of society; welfare of academic staff; and public- private partnerships for resource mobilization.

\section{References}

Abdalla, Y \& Elhadary, E. (2010). 'Higher Education in Sudan' in Alemu K.B., et. al Shaping Research Universities in the Nile Basin Countries, Book 1, Kampala: Fountain Publishers.

African Echo. (2011). The Voice of Africa: University of Timbuktu-The first University in the world. Accessed on 25/09/2011 from http://www.africanecho.co.uk/africanechonews4-mar24.html

Alemu, K.B. (2010). 'The State of Higher Education and Research in Ethiopia' in Alemu K.B., et. al Shaping Research Universities in the Nile Basin Countries, Book 1, Kampala: Fountain Publishers.

Association of Common Wealth Universities. (2011).

Barakamfitiye, L. (2010). L'enseignement Superieur au Burundi', in Alemu K.B., et. al Shaping Research Universities in the Nile Basin Countries, Book 1, Kampala: Fountain Publishers.

Bibangambah, J. R. (2009). 'The Role of a Vice- Chancellor in a University in Uganda,' in Journal of Development Issues Vol. 1 No. 1 December. Mbarara: Faculty of Business and Development Studies, Bishop Stuart University.

El-Rayes, Amani \& Hosam El-Emama, (2010). 'Higher Education and Research in Egypt' in Alemu K.B., et. al Shaping Research Universities in the Nile Basin Countries, Book 1, Kampala: Fountain Publishers.

Esposito, J.L. (2003). Oxford Dictionary of Islam. Oxford Reference Online, Oxford University Press.

Hassan, M.H.A. (2008). Science in Africa: Lessons to Learn. http://www.pataneto.co.uk.

Hsiou-Hsia, T. (2007). 'The Features of a World-class University: Lessons from International Ranking' in Sadlak, J., and Cai, L.N., Higher Education for a Knowledge Society: The World-Class University: Aiming Beyond Status, Bucharest, Shanhai, Cluj-Napoca: UNESCO.

Hsuan Feng, D.V. (2007). 'Generic and Intangible Features of World Class Universities', in Sadlak, J., and Cai, L.N., 
Higher Education for a Knowledge Society: The World-Class University: Aiming Beyond Status, Bucharest, Shanhai, Cluj-Napoca: UNESCO.

http://www.muslimheritage.com/topics/default.cfm?ArticleID=447

International Academic Freedom Workshops. (u.d.). 'Historical Background: Africa.' Accessed on 25/09/2011 from $\mathrm{http}: / /$ www.academicfreedom.info/workshops/a_foundational.html\#Africa

Kanangire, C.K. (2010). 'Higher Education Systems in the Nile Basin: Young Institutions in Search of Identity and relevance' in Alemu K.B., et. al Shaping Research Universities in the Nile Basin Countries, Book 1, Kampala: Fountain Publishers.

Lulat, Y. G-M. (2005). A History of African Higher Education from Antiquity to the Present: A Critical Synthesis, Connecticut: Praeger.

Makerere University, Historical Background. Accessed on 25/09/2011 from http://mak.ac.ug/index.php?option=com_content\&task=view\&id=17\&Itemid=71

Mamdani, M. (2007). Scholars in the market Place: The Dilemmas of Neo-Liberal Reforms at Makerere University, 1989-2005. Kampala: Fountain Publishers.

Materu, P. (2007). 'Higher Education Quality Assurance in Sub-Saharan Africa: Status, Challenges, Opportunities, and Promising Practices', World Bank Working Paper No. 124. Washington, D.C: World Bank. http://dx.doi.org/10.1596/978-0-8213-7272-2

Mwiandi, M.C. (2010). Development of University Education in Kenya since Independence' in Alemu K.B., et. al. Shaping Research Universities in the Nile Basin Countries, Book 1, Kampala: Fountain Publishers.

NCHE. (2011). Quality Assurance Framework for Universities and the Licensing Process for Higher Education Institutions, May 2011.

NCHE, Statutory Instrument No.50 of 2010 - Uganda.

Oke, G.G., et. al. (2010). 'The Relationship between Vice- chancellors' Leadership Behaviour and the Work Behaviour of Lecturers in Nigerian Universities: Implications for Leadership Training for Vice- Chancellors,' in Journal of Higher Education/RESA, 8(1), 123-139, Dakar: CODESRIA.

Teferra, D. \& Altbach, P.G. (2004). African Higher Education: Challenges for the $21^{\text {st }}$ Century. Higher Education, 47, 21-50. http://dx.doi.org/10.1023/B:HIGH.0000009822.49980.30

Tettey, J.W. (2006). Staff Retention in Africa Universities: Elements of Sustainable Strategy, World Bank. Accesses at http://siteresources.worldBank.org.12/10/2011.

Thaver. (2004).

The Kampala Declaration on Intellectual Freedom and Social Responsibility, 1990. Accesses at www.codesria.org. 10/06/2016.

Tjeldvoll, A., et.al. (2005). The Complex Relations Between University, Society and State: The Ethiopian Predicament in Establishing a Service University. RESA, 3(1), 51-57.

Zeleza, P.T \& Olukoshi, A. eds. (2004). African Universities in the Twenty-first Century, 1. South Africa: UNISA Press. 